\title{
Modelling the effects of irrigation reliability on pasture growth in a dairy system in Canterbury
}

\author{
B.S. THORROLD, K.P. BRIGHT, C. A. PALMER and M.E. WASTNEY
}

Dexcel, PB 3221,Hamilton

bruce.thorrold@dexcel.co.nz

\begin{abstract}
The Canterbury Plains is an area of low rainfall, and large pasture growth responses to irrigation have been demonstrated. As the demand for irrigation water has increased, questions about water allocation impacts on dairy farm production and profit have arisen. This study used farm systems modelling to predict the impacts of water allocation on dairy farming. The model farm was based on a spray irrigated farm, fed from the Rangitata River. A multi-year approach with rainfall, temperature and water supply all affected by weather highlighted both average impacts and the variability in impacts between years. Shifting from dryland to irrigated increased yield and decreased annual variability. A 20\% range in water allocated within the four irrigated scenarios gave a $7 \%$ range in pasture yield, but there were no differences in annual variability between scenarios in either water supplied or pasture yield. Analysis of simulation results indicated that clusters of poor years and the relationship between dryland and irrigated yields may be important sources of variability for dairy farmers to consider. Interactions between local climate, the seasonal water supply pattern from different irrigation schemes, soil type and irrigation hardware will influence the impacts of restricting water availability on individual farms. The results of this study emphasise the need to consider the role of water storage, climatic patterns, feed storage, use of run-off blocks and the regional balance of water demands as important factors in reducing production variability on-farm and in the region.
\end{abstract}

Keywords: farm systems, pasture yield, Whole Farm Model, yield variability

\section{Introduction}

The Canterbury Plains is an area of low rainfall, and large pasture growth responses to irrigation have been demonstrated in previous research (McBride 1994). Dairying has expanded in Canterbury in the last decade, mostly on irrigated farms. As the demand for irrigation water has increased, questions about water allocation including avoiding over-allocation and sharing between competing uses have arisen.

In the case of the Rangitata River scheme (RDR), questions were posed about the impact of water allocation on dairy farm production and profit. The allocation system affects the amount of water supplied and the reliability of water supply at times when restrictions on irrigation are imposed.

This study used farm systems modelling to predict the impacts of water allocation on dairy farming. By using a multi-year approach with rainfall, temperature and water supply all affected by weather we aimed to look at both average impacts and the variability in impacts between years.

\section{Methods}

To examine the impact of water allocation systems on a dairy farm, we used the Dexcel Whole Farm Model (WFM) (Wastney et al. 2002). Pasture growth in the WFM is driven by weather (rainfall, radiation and temperature), using the pasture growth model of McCall \& Bishop-Hurley (2003). Winchmore Research Station data from the period 1972-1999 were used for the weather input. Rangitata River flows and evapotranspiration data for this period were analysed to derive a daily irrigation schedule for each of the 30 paddocks on the farm for each year. This schedule included the impacts of regulations controlling the amount of water taken from the river at minimum flows, and the effect of in-channel flow rates on water losses between the river and the farm. Irrigation schedules were prepared for four scenarios (Table 1) based on varying minimum flows in the river and the area of irrigated land in the scheme. The WFM simulated a spray irrigation system capable of applying $30 \mathrm{~mm} /$ application at a six day return period.

The pasture model was parameterised for a shallow Lismore soil, with a plant available water capacity of $25 \mathrm{~mm}$ in the surface horizon and $42 \mathrm{~mm}$ in the subsurface horizon. Nitrogen fertiliser $(30 \mathrm{~kg} \mathrm{~N} / \mathrm{ha} /$ application, 280-290 kg N/ha/yr) was applied to each paddock after grazing. Responses to $\mathrm{N}$ fertiliser were calculated from set monthly response functions, with no temperature or soil moisture interactions.

The model farm was set up with thirty 1.0 ha paddocks carrying 102 Holstein-Friesian cows (average live weight $500 \mathrm{~kg}$ ). Cows were wintered off-farm from 1 June until shortly before start of calving on 5th August and all cows were dried-off on 30 May. To ensure that silage supply was non-limiting, an initial silage stack of 225000 $\mathrm{kg}$ DM of grass silage was assumed. This stack was added to using conservation, and feed was removed from the stack as required to meet cow demand. At the end of 
Table 1 Predicted average pasture yield, irrigation depth and silage bought for each scenario for $1972-99$.

\begin{tabular}{|c|c|c|c|c|c|}
\hline \multirow[b]{2}{*}{ Scenario } & \multicolumn{2}{|c|}{ Pasture grown } & \multicolumn{2}{|c|}{ - Irrigation applied } & \multirow{2}{*}{$\begin{array}{l}\text { Silage bough } \\
\text { kg DM/ha/yr }\end{array}$} \\
\hline & $\mathrm{kg} \mathrm{DM} / \mathrm{ha} / \mathrm{yr}$ & $\begin{array}{c}\text { Relative to } \\
\text { Spray } 1=1.0\end{array}$ & $\mathrm{~mm} / \mathrm{yr}$ & $\begin{array}{c}\text { Relative to } \\
\text { Spray } 1=1.0\end{array}$ & \\
\hline Spray 1 & 15720 & & 523 & & -489 \\
\hline Spray 2 & 14890 & 0.95 & 445 & 0.85 & 220 \\
\hline Spray 3 & 14781 & 0.94 & 434 & 0.84 & 307 \\
\hline Spray 4 & 14553 & 0.93 & 411 & 0.79 & 511 \\
\hline Dryland & 8580 & 0.55 & & & \\
\hline
\end{tabular}

each season the amount of silage required (or sold) to bring the silage stack back to $225000 \mathrm{~kg}$ DM was recorded.

As the cows were fully-fed, milk production $(414 \mathrm{~kg}$ $\mathrm{MS} / \mathrm{cow}$ and $1242 \mathrm{~kg} \mathrm{MS} / \mathrm{ha} / \mathrm{yr}$ ) was the same in each year of every scenario, with differences in silage bought in or surplus representing the economic cost of different levels of irrigation reliability. No carryover effects on cows were included in the model, as we assumed that sufficient supplement and winter feed was available to ensure that calving condition score and in-calf patterns were constant between seasons.

\section{Results}

\section{Irrigation water availability and reliability}

The scenarios varied in the average amount of water available for irrigation. Table 1 shows that water supply was progressively restricted from Spray 1 to 4 . However, the reliability of water supply as expressed by the coefficient of variation (CV) of annual irrigation applied was virtually identical (22-23\%) in all scenarios. The RDR is a run-of-the-river scheme, without storage and with flow restriction on water abstraction. Figure 1 shows the monthly irrigation amount for three scenarios in 199394, which was one of the lowest pasture growth seasons in the period studied.

Figure 1 Monthly irrigation amounts for three Spray scenarios in 1993-94.

$$
\multimap \text { Spray } 1 \rightarrow-\text { Spray } 2 \multimap \text { Spray } 4
$$

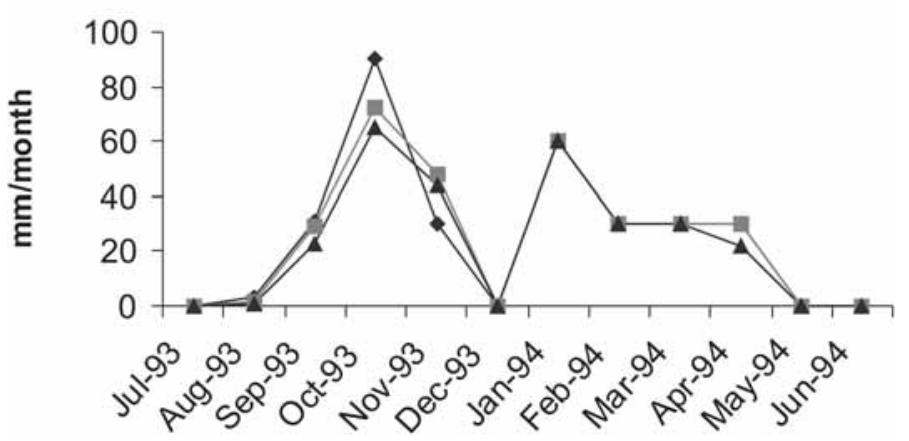

\section{Pasture yield and silage purchased}

Pasture production was strongly influenced by irrigation. Average rainfall in this period was $724 \mathrm{~mm}$. This rainfall supported a yield of $8580 \mathrm{~kg} \mathrm{DM} / \mathrm{ha}$ in the Dryland scenario (Table 1). The WFM predicted an approximate doubling of pasture yield in response to irrigation increasing from Dryland to Spray 1. Restricting irrigation led to losses in pasture yield, Spray 4 received $21 \%$ less water than Spray 1 and produced $7 \%$ less yield. The size of the Dryland-Spray 1 yield response, and the diminishing returns response to additional irrigation from Spray 4 to Spray 1, are consistent with the irrigation responses measured at Winchmore (McBride 1994) with the same soil and climate.

The balance between animal demand and pasture growth allows the Spray 1 farm to grow surplus silage on average ( $489 \mathrm{~kg} \mathrm{DM} / \mathrm{ha} / \mathrm{yr})$, but all other scenarios require additional silage to be purchased to support simulated feed demand.

Variability in pasture yield over the 27 years was much lower in the irrigated scenarios (CV 5.7-6.5\%) than the dryland (CV 23\%). However, the level of irrigation did not affect the $\mathrm{CV}$ of pasture yield.

\section{Variability over time}

Variability in pasture yield has important effects in addition to variation about the annual average. Figure 2 shows the pattern over time of silage bought or sold for Spray 1 and Spray 4. There was variability through time, with two clusters of poor years (large amounts of silage bought) in the 1970s and mid 1990s. While the Spray 1 scenario, on average, produces surplus feed, for three out of four years in the two 'poor' clusters, Spray 1 had a feed deficit.

\section{Links between dryland and irrigated farms}

There was no relationship between simulated pasture yield in the Spray 4 
Scenario and the Dryland Scenario (Figure 3). This is because Dryland production is closely and positively correlated with annual rainfall, while pasture yield on the Spray 4 Scenario was slightly negatively correlated with annual rainfall, despite total water supply increasing with annual rainfall. Possibly lower temperature and radiation in wet years limited pasture yield on irrigated pastures,

\section{Discussion}

\section{Reducing water allocation}

Water allocation to individual dairy farms may be reduced in the future. The WFM simulations show that a permanent decrease in water availability will lead to a decrease in pasture proportional to, but smaller than the decrease in water allocation. This will lead to reduced milksolids production (or increased feeding costs), and in most circumstances, a reduction in income, profit and land value. If the decrease in water availability is severe, the year-to-year variability of production is also likely to increase. None of the reduction scenarios studied here were sufficiently severe to show this effect, however the Dryland-Irrigated comparison does show this trend, as does previous work (McBride 1994) with border-dyke systems.

\section{Managing variability}

All farming is exposed to variability. This study has helped to identify some factors for Canterbury dairy farmers to consider in managing production variability. Greater water allocation under existing supply regimes may not always be the solution to variability. Moving from dryland to irrigation in this study increased the average pasture yield and reduced year-to-year variability. However, within the boundaries of the spray scenarios studied, additional irrigation water did not reduce production variability. Study of water supply patterns (e.g. Figure 1) shows that the run-of-river scheme was unable to supply any scenario with water at low flow times, meaning that the additional water available to Spray 1 was not able to be applied at the times of maximum soil moisture deficit when it would have been most beneficial.

McBride (1994) commented that farmers had moved from an insurance approach to irrigation use to fully utilising the production gains possible. In the succeeding 10 years, dairy farmers have moved even further down
The pattern with time of silage bought (positive) or surplus (negative) for Spray 1 and Spray 4 scenarios. Graph covers the period 1972/1973 to $1998 / 1999$.

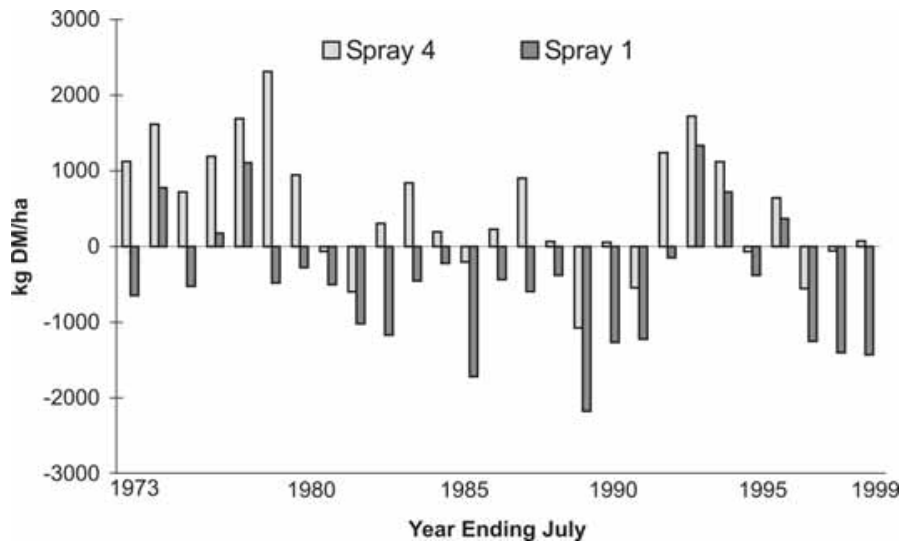

elationship between simulated pasture yield on Spray 4 and Dryland scenarios.

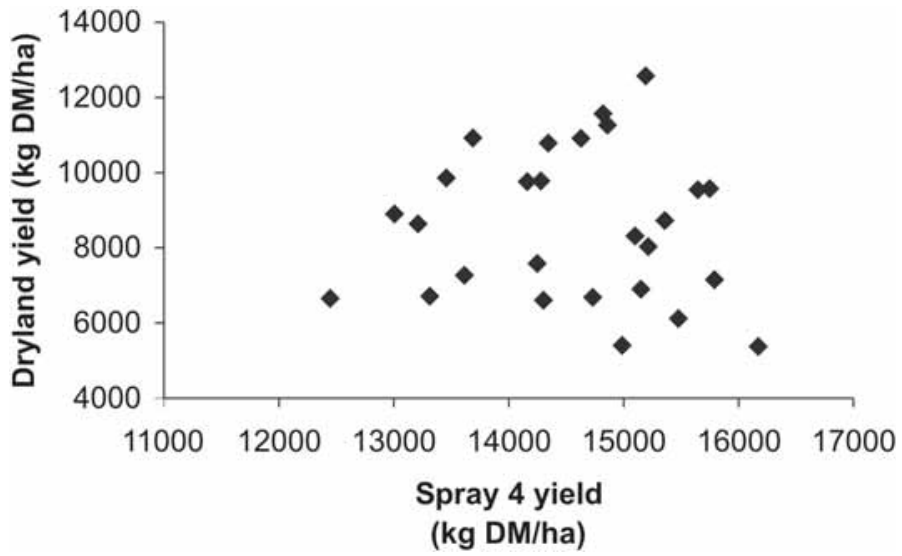

this track and are improving irrigation efficiency, buying in supplementary feed, using more $\mathrm{N}$ fertiliser and winter grazing off-farm to increase stocking rate on the milking platform. By adopting these strategies, farmers fully utilise the spring water and feed peaks, but increase their exposure to summer-autumn water restrictions and failure of silage and winter-feed crops on other farms. The Spray 1 scenario was more easily able to carry the $3.4 \mathrm{cows} / \mathrm{ha}$ simulated by using the additional pasture yield to buffer year-to-year variability. If farmers with this type of irrigation supply increased stocking rate above 3.4 cows/ ha to utilise the additional feed (and then bought in supplement), the variability over time will lead them to have feed deficits when irrigation is restricted as severe as the Spray 4 farm at the lower stocking rate.

The clustering of poor years observed is likely to be more damaging than random variability as cash and feed reserves are depleted and carryover affects accumulate. Clusters reduce the ability of farms to transfer surplus 
feed from good to poor years. The financial impacts of these clusters on farm will be more severe if they coincide with low product price years.

Figure 3 implies that the supply of silage from dryland farms will not be related to demand from Spray farms. On average, this might reduce Spray farm production variability, but it does imply that in the occasional years when poor production occurs on both Dryland and irrigated farms (e.g. 1977/1978, 1991/1992) that silage will be in short supply and probably expensive. The varying patterns of reliability of feed supply between dryland and irrigated properties is further complicated by the effect of timing of summer-autumn rainfall on winter greenfeed crop establishment. This has not been considered at all in this analysis, but should be included in any further study of interrelationships between irrigated and dryland farms.

\section{Conclusions}

More irrigation water will generally produce greater pasture yields. However, more water will not always reduce variability in pasture yield.
Management factors in addition to water supply onfarm (e.g. climatic patterns, feed storage, use of boughtin feed) are important in influencing production variability.

\section{ACKNOWLEDGEMENTS}

This study was funded by MAFPolicy. Development of the Dexcel WFM has been funded by Dairy InSight and the Foundation for Research Science and Technology. We are grateful for the critical and practical input from the project steering group.

\section{REFERENCES}

McBride, S.D. 1994. Pasture yield responses to irrigation in Canterbury. Proceedings of the New Zealand Grassland Association 56: 165-168.

McCall, D.G.; Bishop-Hurley, G.J. 2003. A pasture growth model for use in a whole-farm dairy production model. Agricultural Systems 76: 1183-1205.

Wastney, M.E.; Palliser, C.C.; Lile, J.A.; Macdonald, K.A.; Penno, J.W.; Bright, K.P. 2002. A whole-farm model applied to a dairy system. New Zealand Society of Animal Production 62: 120-123. 